\title{
JURIDICAL REVIEW OF SHIFTED OFFENSE IN COPYRIGHT LAW NUMBER 28 / 2014
}

\author{
Yati Nurhayati \\ Uniska MAB, South Kalimantan, Indonesia \\ nurhayati.law@gmail.com \\ Ifrani \\ Universitas Lambung Mangkurat, South Kalimantan, Indonesia \\ ifrani@ulm.ac.id
}

\begin{abstract}
The objective of this study are: First, to find the reasoning behind changes in offenses in the Copyright Law number $28 / 2014$. Second, reviewing the impact of offense changes and their influence on the enforcement of copyright in Indonesia. This study uses a normative juridical method. Normative legal research is carried out through qualitative descriptive. While the legal material is collected, sorted and subsequently studied and analyzed for content, to obtain the level of synchronization, the feasibility of norms, and the submission of new normative ideas. The results of this study are that the complaint offense in the 2014 Copyright Law is suitable considering that copyright is something unformed. When a complaint is imposed, the copyright owner must know the details of the object of his creation. Changes of offenses in the copyright law need to be supported by the device and law enforcement in Indonesia. It is necessary to make additional regulations on the reporting mechanism and also the mechanism of complaints and reports through civil procedures. The impact of the offense change has become a crucial factor in the enforcement of copyright law in Indonesia. Given that so far the application of normal offenses seems to be running in place because law enforcers become passive and with complaints offense, all stakeholders can protect the copyright of the creator.
\end{abstract}

Keyword: Copyrights, Criminal, Offense.

\section{A. INTRODUCTION}

In Indonesia, in the history of the country, there have been several regulations regarding copyright protection. In a formal juridical manner in 1912 auteurswet (wet van September 23, 1912, Staatblad 1912 Number 600). Which was later merged with the issuance of Law No. 6/1982 on Copyright which governed several affairs the same as the 1912 auteurswet from the Netherlands. In 1987 Law No.
7/1987 was born which was a change from Law No. 6 /1982. In Law No.7/1987 the scale of copyright protection is broader. Including the period of copyright protection extended to 50 years after the death of the creator. Record and video works fall into the protected category. One of the provisions in Law No.7/1982 is that in dealing with copyright infringement, the criminal regulation only uses complaint offenses, so it 
was changed through Law No. 7 /1987 to become a normal offense.

Then in the 1987 copyright law was changed with the issuance of Law No. 12/1997 because Indonesia participated in the Agreement on Trade-Related Aspect of Intellectual Property Rights, Including Trade Counterfeit Goods / TRIPs which is part of the Agreement Establishing the World Trade Organization (Agreement Establishing the World Trade Organization In addition, Indonesia also ratified the Berne Convention for the Protection of Architecture and Literary Works.

Then in 2002, copyright law was renewed again with Law No 19 /2002 on copyright which was later changed to Law No. 28 /2014. One exciting aspect about the recent changes is a change in criminal offense which was initially a normal offense to become a complaint offense. This change is very fundamental because it affects the enforcement of copyright law in Indonesia. Some problems arise so that it is interesting to study the extent to which new copyright protects the creators.

The problem formulation of this study is the reasoning factors behind the change of offense in Copyright Law No. 28 /2014 and seeing the impact of offenses change and its influence on the enforcement of copyright in Indonesia. The methodology has a vital role in the research and development of knowledge because it has several functions. Among others, is to increase the ability of scientists to conduct or carry out research better, or more fully and provide greater possibilities, to examine the unknown. ${ }^{1}$

This study uses normative legal research. This type of research will refer more to the legal norms contained in legislation, court decisions, and common habits. Also thoroughly studies the issues by comparing law in books with the law in action. ${ }^{2}$

Data analysis of normative legal research is carried out in a qualitative descriptive manner. While the legal material is collected, sorted and subsequently studied and analyzed for content, so that the level of synchronization, the feasibility of norms, and the submission of new normative ideas can be review.

\section{B. DISCUSSION}

\section{General Review on Copyrights}

Intellectual Property Right (IPR) ${ }^{3}$ First appeared in Venice (Italy) in 1470 and only related to patents then adopted by the British empire in the 1500 s and began to be adopted by many countries in the world and harmonized in 1883 with the birth of the Paris Convention for the patent, trademarks, and designs. ${ }^{4}$

1 Soerjono Soekanto, Pengantar Penelitian Hukum (Jakarta: Universitas Indonesia, Cetakan Ketiga, 2007), page. 7.

2 David M. Fetterman, Ethnography Step by Step, (London: Sage Publishing, 1998), page. 175.

3 Here and after will refer to as IPR

4 Much. Nurrachmad, Segala Tentang HAKI Indoensia, Buku Biru, Yogyakarta, 2012, page 18 
Substantially, the definition of Intellectual Property Rights can be described as a property right that arises or is born due to human intellectual abilities. ${ }^{5}$ The object protected by law is the idea, not the material form of IPR incarnation. The reason is that IPR is an exclusive right that only exists and is attached to the owner or right holder. ${ }^{6}$

IPR is intellectual property protected by law. Legal protection of intellectual property rights is based on two reasons:

a. First, because in IPR there is a moral right that reflects the personality of the creator. Secondly because of economic factors or commercial rights contained by the intellectual work. The last factor is what drives countries in the world to provide full and firm legal protection intellectual work. ${ }^{7}$ against

b. Both of these factors also describe by three theories of IPR, which are ${ }^{8}$ :

1) Monism Theory. Based on this theory, moral

5 Budi Agus Riswandi dan M. Syamsudin, Hak Kekayaan intelektual dan Budaya Hukum, PT Raja Grafindo, Jakarta, 2004, page 31

6 Abdul Kadir Muhammad, Kajian Hukum Ekonomi Hak Kekayaan Intelektual, PT Citra Aditya Bandung, 2001, page 1

7 Ok Saidin, Aspek Hukum Hak Atas Kekayaan Intelektual, PT Raja Grafindo Persada, Jakarta, 2010, page 111

8 Ibid, page 111 right and commercial right in IPR is a unity which cannot be separate.

2) Dualism Theory. Based on this theory, moral right and commercial right is separable.

3) Modern Theory. Which is a contrary to monism and dualism, pioneered by Ulmer and Schricker. With the modern theory, which argues that both rights are unity, but between them, it contained a separability. This theory is adopted by the majority of countries.

Copyright is a concept adopted from the protection of international IPR, which means a right to copy/reuse. However, according to Tim Lindsey, the word copyright is mistakenly translated into Indonesian as Hak Cipta (right to create), and Hak Mengkopi/Hak Menyalin is a more appropriate term. The copyright gives the creator the rights to control and use his creation, which in essence serves to prevent other parties from copying their work without permission. ${ }^{9}$

Internationally there are many definitions or terminology relating to

9 Tim Lindsey et al., (editor), Hak Kekayaan Intelektual, Suatu Pengantar, (Bandung: Alumni, 2002), page. 6 
Copyright, although each countries member of the WIPO Copyright Treaty provides different definitions, but virtually the same understanding, which is exclusive rights for the creator and recipient of the rights to literary works and artworks. ${ }^{10}$

In Indonesia based on Article 1 paragraph (1) of Law Number 28 /2014 on Copyright, defines that copyright is an exclusive right of the creator that arises automatically based on the declarative principle after work is manifested in a tangible form without reducing restrictions by legislation. This provides clarity that the recognition system of copyright in Indonesia is carried out with the first to use doctrine.

\section{The reasons behind Offense Change in Law No. 28/ 2014 on Copyrights}

Law No. 28 /2014 on Copyright is one of the primary legal products. Because it protected an idea, work, original imagination which then produces economically for its creator. This legal protection must be clear. Therefore this legal product is responsive. Responsive legal products are

10 Suyud Margono, Hukum dan Perlindungan Hak Cipta, (Jakarta: Novindo Pustaka Mandiri, 2003), page. 27 legal products whose character reflects the fulfillment of the demands of both individuals and various social groups in the community to reflect a sense of justice in society. ${ }^{11}$

The main problem concerning the enforcement of Copyright law is the issue of culture and paradigm. Regarding the issue of culture, in the traditional view, that creation is considered as shared property, and even if there is an acknowledgment of individual rights to creation, the form emphasizes the moral aspect of copyright rather than its economic value. $^{12}$

The act or process of controlling by rule or restriction, or a rule or order is having legal force, issued by an administrative agency ${ }^{13}$. Then it defined that to as a law or process of control through rules or prohibitions or rules or orders that have legal powers issued by a governmental institution. In the sense that this law is a

11 Arif Rahman, "Konfigurasi Politik dan karakter Hukum, http//arif rahman.dagdigdug.com, accessed on 12 December 2018

12 Aan Priyatna, Thesis Penegakan Hukum Terhadap Pelanggaran Hak Cipta Dalam pembuatan E-Book, Magister kenotariatan Fakultas Hukum Universitas Diponegoro, Semarang, 2016, page 23

13 Henry Campbell Black, Black's Law Dictionary, Eight edition. West Publishing co 2004, page 1311 
product of administrative institutions.

Satjipto Raharjo

argues that legal protection provides aegis. The theory of legal protection is a theory that examines and analyzes the form or purpose of protection provided by the law to the subject. ${ }^{14}$ The elements listed in the theory of legal protection include ${ }^{15}$ :

a. The form and purpose of protection;

b. Legal subject;

c. The object of legal protection.

According to

Fitzgerald, the theory of legal protection that the law aims to integrate and coordinate various interests in society because in traffic of interest, the protection of particular interests can only be realized by limiting interests of other parties. 16 According to Djumhana, the doctrines that developed in Copyright protection, namely ${ }^{17}$ :

14 Salim dan Erlies Septiana Nurbani, Penerapan Teori Hukum Pada penelitian Tesis dan Disertasi, Jakarta:PT Raja Grafindo Persada, 2013, page 263

15 Satjipto Rahardjo, Ilmu Hukum, Bandung;PT Citra Aditya Bakti,2000, page .263

16 Rita Teresia, "Perlindungan Hukum hak Cipta Terhadap Pemilik Lagu Atas Perbuatan pengunduhan Lagu Melalui Situs Tanpa Bayar di Internet", Skripsi. Program Sarjana Hukum Universitas Riau, Pekanbaru, 2015, page 10

17 Hasbir Paserangi, Perlindungan Hukum Hak Cipta Software program Komputer di Indonesia, jurnal hukum Ius Quia Iustum, fakultas Hukum UII, Vol 18 Oktober 2011, page 24 a. Right of Publicity;

b. Making an available right and merchandising right;

c. Fair use/ fair dealing;

d. The work made for hire doctrine;

e. Legal protection of character right;

f. Traditional knowledge in copyrights

g. The latest development in copyright: software, free, copyleft, open source.

The difference between crime and violation of the law are ${ }^{18}$ :

a. Imprisonment only applicable to crimes;

b. In formulating a criminal act, the element of guilt is necessary (intentional or negligence), and needs to be proven by the prosecutor, while in formulating violation this aspect is not necessary;

c. The attempt of violation cannot be prosecuted;

d. The statute of limitation, to determine or serve a sentence is one year for the violation, while for crimes took two years.

Criminal acts are prohibited by a legal rule which is accompanied by threats (sanctions) in the form of individual punishment, for those who violate the prohibition. ${ }^{19}$ In Dutch the crime is called

18 Moeljatno, Asas-asas Hukum Pidana, Jakarta; Rineka Cipta, 2008, page 81

19 Moeljatno, Asas-asas Hukum Pidana, Rineka Cipta, Jakarta: 2002, page.54. 
"straafbaar feit" which consists of the words "straffbaar" and "feit", straffbaar is interpreted as punished and feit means reality. So straafbaar feit is part of the fact that it can be punished. ${ }^{20}$

In Criminal Law, there are two types of offense namely, normal offenses and complaint offense. The offense is one of the essential things that underlie the amendment to Copyright Law No. $28 / 2014$. In the 2002 Copyright Law Article 72 (1) categorize violations of rights as a normal offense. This is following the primary nature of criminal law, namely that its implementation is not dependent on an agreement or complaint from the aggrieved party. Whereas it is known in general, that most of the practices of the state regulate the threat of criminal penalties against violations of IPR is a complaint offense.

In positive Indonesian law, complaint offense can only be processed if it is complained by someone who feels disadvantaged or has become a victim. Therefore, the law enforcer cannot take the initiative to follow up on a case such as in normal offense, and in the compliant offense, the victim can revoke the report if the

20 Evi Hartanti, Tindak Pidana Korupsi, Sinar Grafika, Jakarta: 2005, page. 5. problem is resolved without taking legal action.

There are two types of complaint offenses, namely absolute and relative. An absolute complaint is an offense that can only be processed if there is a complaint. Examples are listed in Articles 284, 287, 293, 310, 332, 322, and 369 of the Penal Code. Meanwhile, the relative complaint is an offense that usually is a normal offense, but can become a complaint if reported by relatives as stipulated in Article 367 of the Penal Code. The articles which constitute relative complaint offenses in the Penal Code are Article 367, 370, 376, 394, 404, and 411. In this case, the perpetrators can be prosecuted selectively and not all of them should be reported.

Complaints can only be submitted within six months after knowing that a crime has occurred, or within nine months if he lives outside Indonesia (as regulated by Article 74 paragraph 1 of the Penal Code). Article 75 of the Penal Code also states that complaints can be revoked within three months after filing. Complaints that have been revoked generally cannot be filed again.

As an offense, the prosecution depends on the willingness of those affected by criminal acts or those who 
have an interest, in other words, those who have been charged with a crime have a role in determining whether the offender is prosecuted or not. Because prosecution is left to the will of victims, it is thus open to the possibility of an alternative settlement between those affected by the crimes as a resolution outside the interference of law enforcement ${ }^{21}$.

$$
\text { In reality, the }
$$

alternative settlement for certain crimes is often felt to be better and more beneficial than the judicial system. The loss of settlement through legal means, among others, is not familial in nature so that it can stretch family relations, and from a legal standpoint the process of settlement is quite long, especially if it reaches the Supreme Court level which takes years so that demands for justice from those affected by crime may no longer be feel fulfilled because the matter itself has been forgotten. ${ }^{22}$

Regarding complaints, the Criminal Code also does not provide a limit of meaning because perhaps in this case, the drafting of the Penal Code considers more precisely if the meaning of

21 Harahap, M. Yahya, SH, Pembahasan Permasalahan dan Penerapan KUHAP, Jilid I, PT. Sarana Bakti Semesta, 1986.

22 Hamzah, Andi, Dr, SH, Pengantar Hukum Acara Pidana, Gpageia Indonesia, 1987. complaint deemed necessary to be formulated explicitly, more precisely formulated in the Procedure of Penal Code , because the complaint is one of the legal efforts that is required for certain offenses in the context of the process of resolving a criminal case. P. A. F. Lamintang in one of his writings, gave a limit regarding complaints as follows: "What is meant by klacht or complaint is a report with a request to be prosecuted against a certain person or persons ${ }^{23}$

The consideration in revising the 2002 Copyright Law which recognizes copyright infringement as a normal offense, there are three reasons that can at least be used as a basis for changes $^{24}$ :

a. First, law enforcers cannot determine whether the violation has occurred only by comparing the goods resulting from copyright infringement with the original creation. Only the creator or copyright holder can be more confident to recognize which is the original

23." Drs. P. A. F. Lamintang, SH, Dasardasar Hukum Pidana Indonesia, Sinar Baru, Bandung, 1984, page. 209.

24 Legislative Draft Team under Prof Abdul Gani Abdullah, Kajian TIM NASKAH AKADEMIK RANCANGAN UNDANG UNDANG TENTANG CIPTA (Perubahan UU No. 19 Tahun 2002), Jakarta, Departemen Hukum dan HAM RI, 2008 
creation and the imitation of the original creation so that it can immediately report the occurrence of a violation of the exclusive rights of his creation.

b. Secondly, in carrying out legal proceedings, law enforcers may not immediately know whether a party has obtained permission to reproduce a work. Therefore, there must be a complaint in advance from the creator or the copyright holder.

c. Third, in practice, if copyright infringement occurs, the creators prefer compensation from the party who infringes the copyright rather than the imprisonment.

The legal connection between the creator and the suspect is mostly private to private (privaaatrechtelijk). So it is more appropriate to use passive systems, such as complaint offense. The normal offense for the 2002 Copyright Law means that law enforcement is not dependent on an agreement or complaint from a party who has been harmed by a criminal act but rather is handed over by the officials to determine whether and where the criminal threat is against Copyright violations are conducted using public interests ${ }^{25}$.

In practice, this is very detrimental to the creator. The copyright is an exclusive right, so ideally the violation should be implementing a complaint offense because the person who knows the existence of the violation is the creator himself. This is further clarified by the burden of proof, where investigators are perceived as having difficulties in proving the existence of criminal acts in the copyright field without reports from the owners. As already explained that copyright based on the declarative principle after work is manifested in a tangible form without reducing restrictions according to the provisions of the legislation. ${ }^{26}$ Even though the complaint is indeed applied to the Copyright Law, it must be understood that not all criminal provisions in IPR must be regulated by complaint offense. Separation is needed to understand the essential factors to determine an offense in IPR.

The theory of retribution for criminal law is very primitive, but its influence is still felt important in modern times because the primitive element in criminal law is indeed a still more or

25 Prodjodikoro, Wirjono. Azas-Asas Hukum Pidana Indonesia. (Bandung: PT. Eresco, 1986) page 81

26 Article 1 number 1 Law No. 28 /2014 
less needed. ${ }^{27}$ This is to maintain the legal function as a tool of social control, that law enforcement and criminal orientation are adjusted to the crime rate and conditions of each country.

\section{The Impact of Shifting Offense and The Influence of Complaint Offense on the Copyright Enforcement in Indonesia}

Based on the analysis, the offense consists of two main elements, which are, the principal subjective element, namely the principle of penal law "geen straf zonder schuld (No crime without guilt)". The guilt intended here is intentional and negligent. Second, the main objective element, namely human action which is an act and omission. Acts are active actions or positive actions. While omission is an inactive action or adverse action. In other words, it is silence or letting go. ${ }^{28}$

In the Law, it is said that no one can be punished unless a sentence has been determined based on the law. According to Moeljatno, the word "deed" in "criminal deeds" has an abstract

27 Andi Hamzah, Sistem Pidana dan Pemidanaan dari Retribusi ke Reformasi, Jakarta, Pradnya Paramita, 1986), page. 16.

28 Leden Marpaung, Unsur-unsur Perbuatan yang Dapat Dihukum, (Jakarta; Sinar Grafika, 1991), page. 67 meaning which is an understanding that points to two actual events, namely the existence of certain events and the existence of people who act to cause an incident. $^{29}$

The 2014 Copyright law regulates the enforcement through criminal law and civil law in the use of copyrighted songs on the internet or downloading songs on the internet as stipulated in Article 113. ${ }^{30}$ However, the proof will be difficult because using internet media is not easy. This digital media is complicated to prove for private or for commercial purposes.

The civil instruments can also be linked to the enforcement of copyright law under the 2014 Copyright Law. In civil law can be imposed based on acts against the law. The violation of the law is a violation of the individual rights of others. Downloading and even commercially exploiting

29 Seoharto, Hukum Pidana Materiil, (Jakarta; Sinar Grafika, 1993), page. 22

30 Article 113 (3) stated: "Setiap orang yang dengan tanpa hak/dan atau tanpa izin pencipta atau pemegang Hak Cipta melakukan pelanggaran hak ekonomi pencipta sebagaimana dimaksdu dalam Pasal 9 ayat (1) huruf a, hurufb, huruf e dan/atau huruf $g$ untuk penggunaan secara komersial dipidana dengan pidana penjara paling lama 4 (empat) tahun dan/atau pidana denda paling banyak Rp. 1.000.000.000 (satu miliar rupiah)". 
someone's copyright data is said to violate the economic rights of copyright holders who have exclusive rights to exploit economic rights contained in copyright. ${ }^{31}$

The elements of against the law are carried out because they have violated the exclusive rights of the copyright holder and/or the owner. This compensation can be requested by the copyright owner. Compensation is the payment of a sum of money charged to the perpetrator of the violation of economic rights of the creator based on a court decision on civil or criminal cases that has permanent legal power for losses suffered by the creator or copyright holder. These are all contained in Article 1 (25) of the 2014 Copyright Law. Civil lawsuits based on illegal acts are intended to claim compensation.

Copyright owners file lawsuits to commercial courts or mediation and arbitration bodies of intellectual property rights under the provisions of article 95 (1) and (2) of The 2014 Copyright Law whereas Article 99 (1) states that the creator has a right to file a claim for compensation to the

$31 \mathrm{~A}$ civil lawsuit is filed according to article 1365 of the Civil Code on acts against the law as Article 1365 states that any act that violates the law, which brings harm to another person, requires the person who caused the wrong to bring the loss, compensating for the loss. commercial court for copyright infringement or related rights products.

Changes of offenses not automatically protect the exclusive rights of the creator itself. However, the state has provided a clear forum and protection for the creator to be able to file a copyright infringement. With the change in the offense being a complaint, then it is hoped that the judicial process will be more straightforward because the plaintiff is the creator.

The criminal enforcement in Article 120 is a complaint offense so that it can be done with the report from the aggrieved party. Enforcement of criminal law of copyright infringement is carried out by investigators of the Republic of Indonesia National Police and Civil Servants in the ministry in the field of IPR. In addition, changes to regulations regarding offenses complaints, more aspirational. Because in fact in the technological development, many creators who benefit from uploading their creation to the internet to be more widely known to the public. Current developments in technology and information, sometimes creators deliberately upload their works to the public to be freely accessed.

This means that the advances in technology and 
information on the internet violate the copyright on the one hand, but on the other hand, there are creators who want to be known to the public. Thus, the application of the complaint offense is adequately used in Copyright law in the case of the creator who wants to report a loss. Also, efforts made by the government and the Copyright Council provide knowledge to the public regarding the importance of copyright to be respected because it has economic and moral values in it. ${ }^{32}$

\section{CONCLUSION}

Based on the description above, conclusions of this research are complaint offense is suitable when applied in the current Copyright Law. Considering copyright is unformed. When a complaint is imposed, the copyright owner knows the details of the object of his creation. The impact of offense changes is very essential in the enforcement of copyright law in Indonesia. Given that so far the application of normal offenses seems to be running in place because law enforcers become passive, all stakeholders could together protect the copyright of the creator. Changes of offenses in the copyright law need to be supported by the device and law enforcement in Indonesia. It is necessary to make additional regulations on the

32 Syafrinaldi, Hak Milik Intelektual dan Globalisasi, (Riau, UIR Press, 2006), page 37 reporting mechanism and also the mechanism of complaints and reports through civil procedures. 


\section{Books}

\section{REFERENCE}

Fetterman, David M. 1998. Ethnography Step by Step. (London: Sage Publishing)

Goldwin, George. 1957. Criminal Man, New York, George Braziller Inc.

Hamzah, Andi. 1986. Sistem Pidana dan Pemidanaan dari Retribusi ke Reformasi, Jakarta, Pradnya Paramita.

Lindsey, Tim. et.al., (editor). 2002. Hak Kekayaan Intelektual, Suatu Pengantar, (Bandung : Alumni)

Margono, Suyud. 2003. Hukum dan Perlindungan Hak Cipta, (Jakarta: Novindo Pustaka Mandiri)

Remmelink, Jan. 2003. Hukum Pidana; Komentar Atas Pasal Pasal Terpenting dari Kitab Undang-Undang Hukum Pidana Belanda dan Padanannya dalam Kitab Undang-Undang Hukum Pidana Indonesia, (Jakarta: Gramedia Pustaka Utama)

Soekanto, Soerjono. 2007. Pengantar Penelitian Hukum, Jakarta: Universitas Indonesia)

Subekti. 1994. Pokok-pokok Hukum Perdata, (Jakarta : Intermasa)

Bernard L, Tanya, dkk, 2010. Teori Hukum Strategi Tertib Manusia Lintas Ruang dan Generasi, (Yogyakarta: Genta Publising)

Much. Nurrachmad. 2012. Segala tentang HAKI Indonesia, (Buku Biru, Yogyakarta)

Budi agus Riswandi dan M. Syamsudin. 2004. Hak Kekayaan intelektual dan Budaya Hukum, (PT Raja Grafindo, Jakarta)

Abdul Kadir Muhammad, 2001. Kajian Hukum Ekonomi Hak Kekayaan Intelektual (PT Citra Aditya ;Bandung)

Ok Saidin, 2010. Aspek Hukum Hak Atas Kekayaan Intelektual (PT Raja Grafindo Persada; Jakarta)

Syafrinaldi, 2006. Hak Milik Intelektual dan Globalisasi, (Riau, UIR Press)

Leden Marpaung, 1991. Unsur-unsur Perbuatan yang Dapat Dihukum, (Jakarta; Sinar Grafika)

Seoharto, 1993. Hukum Pidana Materiil, (Jakarta; Sinar Grafika)

Wahid, Abdul dan Labib, 2010. Kejahatan Mayantara (cyber crime), (Bandung, PT. Refika Aditama, Bandung)

Prodjodikoro,Wirjono, 1986. Azas-Asas Hukum Pidana Indonesia. (Bandung: PT.Eresco) 
Hamzah, Andi, Dr, SH, 1987. Pengantar Hukum Acara Pidana, (Ghalia Indonesia)

Drs. P. A. F. Lamintang, SH, 1984. Dasar-dasar Hukum Pidana Indonesia, (Sinar Baru, Bandung)

Bernard Nainggolan, 2011. Pemberdayaan Hukum Hak Cipta dan lembaga Manajemen Kolektif (Bandung; PT Alumni Bandung)

Sophar Maru Hutagalung, 2012. Hak Cipta Kedudukan \& Peranannya Dalam pembangunan, (Sinar Grafika, Jakarta)

J. Satrio, 2005. Hukum Jaminan : Hak Jaminan Kebendaan Fidusia, (Bandung: Penerbit PT. Citra Aditya Bakti)

Saidin, 2010. aspek hukum kekayaan intelektual (intelectuall Property Rights) (Rajawali Press, Jakarta)

Iswi Hariyani, 2010, Prosedur mengurus HAKI yang benar, (Pustaka Yustisia, Yogyakarta)

Sri Rejeki Hartono dalam Sentosa Sembiring, 2002. Hak Kekayaan Intelektual dalam Berbagai Perundang-undangan, (Bandung : Yrama Widya)

Ermansyah Djaja, 2009. Hukum Hak Kekayaan Intelektual, (Sinar Grafika, Jakarta)

\section{Legislation}

Republik Indonesia, Undang-Undang Dasar Negara Republik Indonesia Tahun 1945

Undang-Undang Nomor 28 Tahun 2014 Tentang Hak Cipta

Undang-Undang Nomor 19 Tahun 2002 Tentang Hak Cipta

\section{Journal and Research}

A. Aziz Muhammad, (2017) "Konvensi Internasional Tentang Hak Cipta Dan Pengaturan Hak Cipta Di Indonesia", Social Justitia Vol. I No. 1 July.

Agung Sujatmiko, (2010). Prinsip Hukum Penyelesaian Pelanggaran Passing Off Dalam Hukum Merek, Jurnal Yuridika Vol. 25 No. 1, Januari-April 2010.

Ari Wibowo, (2015) "Justifikasi Hukum Pidana terhadap Kebijakan Kriminalisasi Pelanggaran Hak Cipta, Serta Perumusan Kualifikasi Yuridis dan Jenis Deliknya" Jurnal Hukum Ius Quia Iustum No. 1 Vol. 22 Januari 2015

Abu Churairah dkk. (2011), "Perlindungan Hukum Dalam Pendaftaran Ciptaan Seni Lukis (Studi Kasus Putusan Pengadilan Niaga Medan nomor 05/Hak Cipta/2008/PN. Niaga. Mdn.)", Jurnal Mercatoria Vol. 4 No. 1.

Trias Palupi Kurnianingrum, Materi Baru Dalam Undang-Undang Nomor 28 Tahun 2014 tentang Hak Cipta, 
https;//jurnal.dpr.go.id/index.php/hukum/article/view/249/190 diakses tanggal 15 desember 2018

http;//repository.unhas.ac.id.4001/digilib/files/disk1/364/--andikurnia-18170-1andikur-pdf, diakses pada 10 desember 2018

Tim Naskah Akademik di bawah Pimpinan Prof Abdul Gani Abdullah, Kajian TIM NASKAH AKADEMIK RANCANGAN UNDANG UNDANG TENTANG CIPTA (Perubahan UU No. 19 Tahun 2002), Jakarta, Departemen Hukum dan HAM RI, 2008

Hak cipta, http//id.wikipedia.org, diakses tanggal 15 Desember 2018

Arif Rahman, "Konfigurasi Politik dan karakter Hukum, http//arif rahman.dagdigdug.com, diakses pada 12 desember 2018

Henry4w, "Bab II Politik Hukum", http;"www.docstoc.com/docs/37753856/BABPolitik-Hukum, access on 9 December 2018, 